\title{
Erratum to: physiotherapy programme reduces fatigue in patients with advanced cancer receiving palliative care: randomized controlled trial
}

\author{
Anna Pyszora $^{1}$ - Jacek Budzyński ${ }^{2}$ - Agnieszka Wójcik ${ }^{3}$. \\ Anna Prokop ${ }^{4} \cdot$ Malgorzata Krajnik $^{1}$
}

Published online: 15 June 2017

(C) Springer-Verlag GmbH Germany 2017

\section{Erratum to: Support Care Cancer}

DOI 10.1007/s00520-017-3742-4

Unfortunately, the original version of this article contained an error. Affiliations 1 and 2 are now corrected in this article

The online version of the original article can be found at http://dx.doi.org/ $10.1007 / \mathrm{s} 00520-017-3742-4$

\footnotetext{
$\triangle$ Anna Pyszora

aniap30@wp.pl

Jacek Budzyński

budz@cps.pl

Agnieszka Wójcik

maw5@tlen.pl

Anna Prokop

agajewska@vp.pl

Małgorzata Krajnik

malgorzata.krajnik@wp.pl

1 Department of Palliative Care, Nicolaus Copernicus University in Torun, Ludwik Rydygier Collegium Medicum in Bydgoszcz, Skłodowskiej - Curie 9, 85-094 Bydgoszcz, Poland

2 Department of Vascular and Internal Diseases, Nicolaus Copernicus University in Torun, Ludwik Rydygier Collegium Medicum in Bydgoszcz, Ujejskiego 75, 85-168 Bydgoszcz, Poland

3 Faculty of Rehabilitation, Józef Piłsudski University of Physical Education in Warsaw, Marymoncka 34, 00-968 Warszawa, Poland

4 The Blessed Father Jerzy Popiełuszko Hospice in Bydgoszcz, Ks. Prałata Biniaka 3, 85-862 Bydgoszcz, Poland
} 